\title{
Neuro-Behçet: differential diagnosis of recurrent meningitis
}

\author{
ANDREYA FONSECA CARDOSO ${ }^{1}$, PEDRO AUGUSTO ROCHA-FILHO ${ }^{1,2}$, \\ ANA ROSA MELO CORREA-LIMA ${ }^{1}$
}

Division of Neurology Hospital Universitario Oswaldo Cruz, University of Pernambuco, Brazil. ${ }^{1} \mathrm{MD},{ }^{2} \mathrm{PhD}$

Recibido el 20 de mayo de 2012, aceptado el 4 de septiembre de 2012.

Corresponding author: Pedro Augusto Sampaio Rocha Filho, Rua das Creoulas, 78/103 -52011 270 Recife PE - Brasil. E-mail: pasrf@ig.com.br.

\section{ABSTRACT}

Behçet disease is a systemic inflammatory perivasculitis characterized by recurrent episodes of oral and genital ulcers associated with skin and ocular lesions. Neurological involvement occurs in 5 to $10 \%$ of the cases, and isolated meningeal involvement is very uncommon. We report a 21 years old man with a Behçet disease and a history of acute meningeal syndrome in two previous crises and meningoencephalitis in three others. He reported a history of conjunctivitis and oral and genital ulcers. On examination, he presented oral aphthoid lesions, macular edema, involvement of cranial nerves, pyramidal signs and meningeal irritation. The cell count in cerebrospinal fluid was $1800 \mathrm{cells} / \mathrm{mm}^{3}$, with polymorphonuclear predominance. Magnetic resonance imaging showed lesions in basal ganglia and the brainstem. The patient improved dramatically after intravenous steroid therapy.

(Rev Med Chile 2013; 141: 114-118).

Key words: Behçet Syndrome; Meningitis, Aseptic: Nervous System Diseases.

\section{Presentación de enfermedad de Behçet como meningitis recurrente. Informe de un caso}

La enfermedad de Behçet is una perivasculitis sistémica inflamatoria caracterizada por episodios recurrentes de úlceras orales y genitales asociadas a lesiones cutáneas y oculares. El 5 a 10\% de los casos tiene compromiso neurológico y el compromiso meníngeo aislado es muy poco común. Presentamos un hombre de 21 años con enfermedad de Behçet y una historia de sindrome meningeo en dos crisis previas y meningoencefalitis en tres otras. El paciente tenía una historia de conjuntivitis y úlceras orales y genitales. Al examen se encontraron lesiones aftosas, edema macular, compromiso de nervios craneanos, signos piramidales e irritación meningea. El recuento celular del líquido cefalorraquídeo fue de 1.800 células/ml con predominancia polimorfonuclear. La resonancia magnética mostró lesiones en los ganglios basales y tronco encefálico. El paciente mejoró dramáticamente con el uso de corticoides endovenosos.
B ehçet's disease (BD) is a multisystemic inflammatory perivasculitis of unknown etiology. It is a heterogenous disease at its initial presentation, which may be one of the factors that impairs prompt recognition and hence early diagnosis, thereby possibly giving rise to increased morbidity and mortality ${ }^{1}$.
According to the international criteria for diagnoses of $\mathrm{BD}$, patients need to present oral ulcerations that recurred at least three times in one 12-month period and at least two of the following: repeated genital ulcers, ocular lesions (uveitis or cells in vitreous on slit lamp examination or retinal vasculitis), skin lesions (erythema nodosum 
or pseudofolliculitis or papulopustular lesions or acneiform nodules following adolescence) or a positive pathergy test. All of these criteria will only be valid in the absence of any other clinical explanation ${ }^{2}$.

Neurological involvement occurs in 5.3 to $14.3 \%$ of the patients, and the nonspecific nature of its symptoms means that there has to be a high degree of suspicion of a diagnosis of Neuro-Behçet ${ }^{1}$. Around $80 \%$ of the more severe neurological cases affect the cerebral parenchymal, particularly the structures of the brainstem, diencephalon and/ or basal ganglia ${ }^{3}$. Among the non-parenchymatous manifestations, dural sinus thrombosis, arterial vasculitis, intracranial aneurysms and aseptic meningitis alone can be highlighted ${ }^{1,3}$. Poor prognostic factors in Neuro-Behçet include multifocal involvement, spinal presentations, more than two attacks per year, progressive course and increased cerebrospinal fluid cell count and protein content at the time of neurologic manifestations ${ }^{4}$.

There are no clinical trials on management of the neurological aspects of the disease. First-line drug include corticosteroids, azathioprine, methotrexate, and cyclophosphamide. Second-line drugs are tumor necrosis factor alpha blocking drugs, interferon-alpha, chlorambucil, and mycophenolate mofenil ${ }^{5}$.

Here, we report on a case of $\mathrm{BD}$ in which the neurological manifestation was prominent acute meningeal syndrome alone in the first two episodes and meningoencephalitis in the last three episodes.

\section{Case report}

A 21-year-old man, attended at our clinic in June 2009, had a history of thunderclap heada- ches, náusea, vomiting, neck pain and fever, and followed by a focal neurological deficit.

He had four previous events, the first one in January 2008. In the first two, it was limited to meningeal syndrome and intracranial hypertension. These had been interpreted as bacterial meningitis and treated with antimicrobial agents and dexamethasone. A clinical improvement was achieved within ten days.

From the third episode onwards, the meningeal condition was accompanied by left-side hemiparesis and corresponding abnormalities on imaging examinations. The neurological deficit presented almost complete reversion after intravenous corticoid therapy.

In the present event (fifth episode), in addition to the condition of meningeal irritation and worsening of left-side strength, there was a complaint of diplopia and dysphonia.

The patient mentioned that he had had epigastralgia, phlogistic signs in skin areas subjected to minimal trauma, knee arthralgia, acneiform lesions on his face and repeated conjunctivitis. He had five episodes of sudden appearance of aphthoid lesions located on the tongue and lips and three of genital ulcers in the scrotal region over the preceding eight months. These lesions regressed spontaneously after a few days.

The physical examination showed an aphthoid lesion in the internal part of the lower lip, macular edema bilaterally in an analysis of the eye, paresis of the left-side IX and X cranial nerves and the right-side VI and XII nerves, left-side hemiparesis, and signs of meningeal irritation.

The erythrocyte sedimentation rate was 25 $\mathrm{mm} / \mathrm{h}$. Serum assays on anti-DNA antibodies, anti-nuclear factor, anti-neutrophil cytoplasmic antibodies (p-ANCA and c-ANCA), and the se-

Table 1. Cerebrospinal fluid results in the five episodes of Neuro-Behçet

\begin{tabular}{|lccc|}
\hline Date of each episode & Cells/mm & $\begin{array}{c}\text { Protein } \\
\text { (mg/dl) }\end{array}$ & $\begin{array}{c}\text { Glucose } \\
\text { (mg/dl) }\end{array}$ \\
\hline Episode 1 (January/ 2008) & $2.500(90 \%$ PMN) & 105 & 50 \\
\hline Episode 2 (July/ 2008) & $1.500(90 \%$ PMN) & 60 & 70 \\
\hline Episode 3 (January/ 2009) & $1.800(80 \%$ PMN) & 77 & 31 \\
\hline Episode 4 (April/ 2009) & $1.330(80 \%$ PMN) & 49 & 62 \\
\hline Episode 5 (June/ 2009) & $1.800(90 \%$ PMN) & 87 & 53 \\
\hline
\end{tabular}

$\mathrm{PMN}=$ Polymorphonuclear cells. 


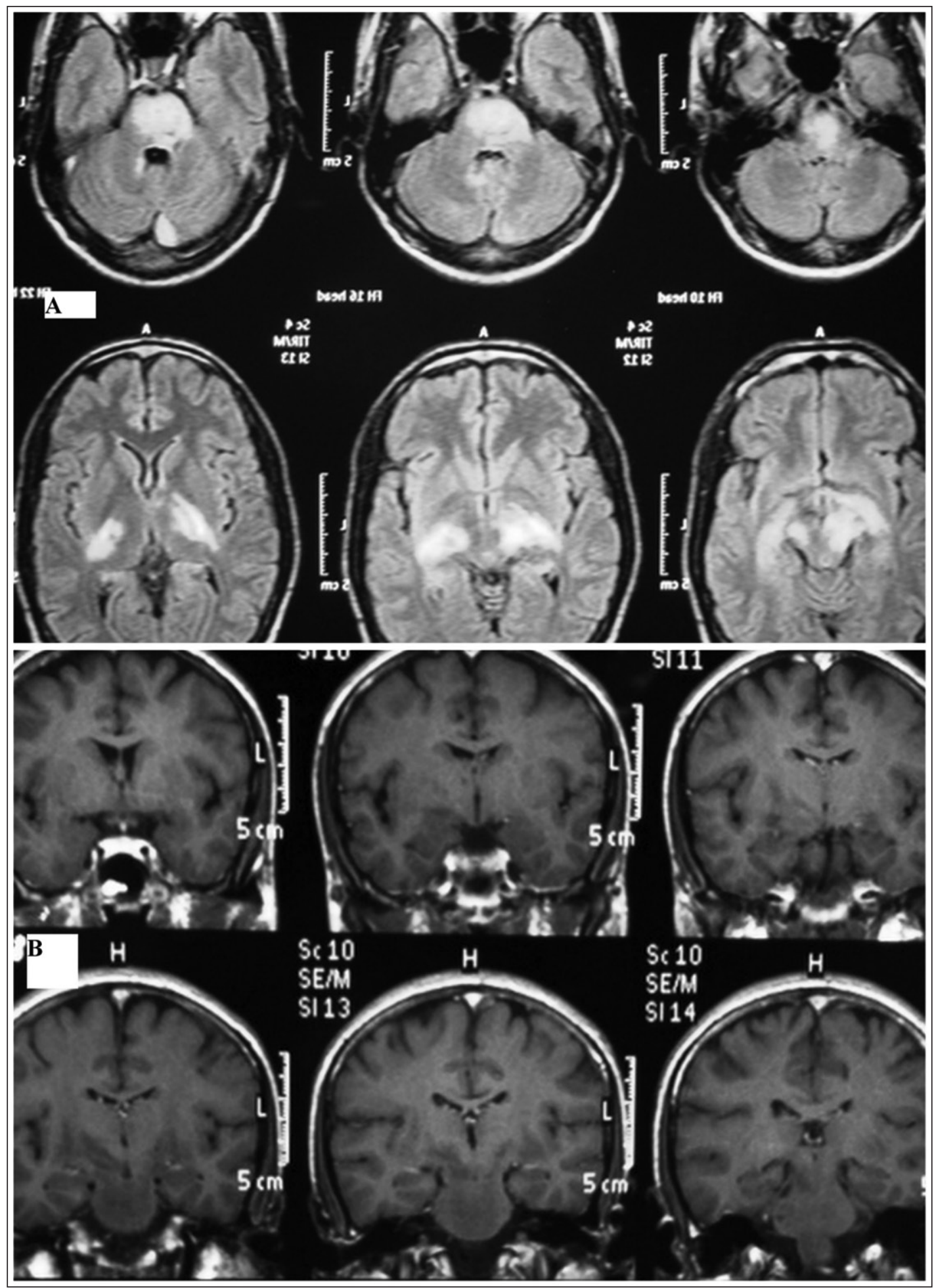

Figure 1. A) Hyperintense T2 and FLAIR-weighted lesions in thalamus, mesencephalic peduncle, pons and right bulb. B) Postgadolinium T1-weighted images. There is no enhancement of the lesions following IV gadolinium injection. 
rological test for the human immunodeficiency virus (HIV), were negative.

The CSF analysis showed a cell count of 1800 cells $/ \mathrm{mm}^{3}$ with predominance of polymorphonuclear cells (Table 1). Tests for herpes, CMV, HIV, schistosomiasis and cysticercosis were negative. Gram, latex and cultures were negative for pyogenic germs. There were no oligoclonal bands, and VDRL was unreactive. The results retrieved from the previous four episodes showed similar findings.

Magnetic resonance imaging (MRI) on the encephalon, using Gadolinium-based contrast, showed a hyperintense signal in T2 and FLAIRweighted sequences, for the thalamus, mesencephalic peduncle, pons and right bulb, without repercussion on diffusion (Figure 1). MRI investigation of the cervical spinal cord did not reveal any abnormality. Cerebral digital arteriography diagnosed two aneurysms of dimensions less than $2 \mathrm{~mm}$ in both ophthalmic carotid arteries.

The histopathological finding from the labial lesion was nonspecific vasculitis. The pathergy test, done while the patient was undergoing treatment with high doses of corticosteroids, was negative.

A diagnosis of Neuro-Behçet was made. The patient underwent pulse therapy with methylprednisolone for five days, followed by oral prednisone at a dose of $1 \mathrm{mg} / \mathrm{kg}$ per day. Despite the dramatic improvement in the neurological condition, persistence of the macular edema justified increasing the maintenance dose of prednisone to $1.5 \mathrm{mg} /$ $\mathrm{kg}$ per day and starting oral immunosuppressant therapy with azathioprine. There was complete remission of the MRI findings from the encephalon.

After two years of follow-up, the patient is continuing to use oral immunosuppressant medication without addition of corticosteroids and the disease is under control from both the neurological and the dermatological point of view.

\section{Discussion}

Our patient presented clinical criteria for $\mathrm{BD}^{2}$ and evolved with signs and symptoms compatible with mixed neurological involvement in BD (parenchymatous involvement: meningoencephalitis; and non-parenchymatous involvement: meningeal reaction and intracranial aneurysms) $)^{1}$.

Meningeal signs and symptoms may be present in parenchymatous disease, thus characterizing cases of meningoencephalitis. Meningeal conditions alone are found in only 1 to $1.4 \%$ of NeuroBehçet cases, and could happen in patients that do not fulfill criteria for $\mathrm{BD}^{6}$. It is essential to rule out infectious meningitis ${ }^{3,7}$. Serum procalcitonin, which is usually elevated in bacterial meningitis, generally was not increased Neuro-Behçet cases and might help in discrimination between the both conditions ${ }^{8}$. In our case, causes of recurrent meningitis such as congenital neuroectodermal sinus and cerebrospinal fluid fistulas (bacterial meningitis), cysticercosis, Lyme disease, Sjögren's syndrome, primary angiitis of the central nervous system, systemic lupus erythematosus, systemic necrotizing vasculitis, drug-induced allergic reactions must be considered.

In our case, the cellularity of the CSF was higher than the mean reported in the literature, and this was associated with the predominance of polymorphonuclear cells. The absence of other neurological signs than of meningeal irritation and difficulty in acquiring confirmatory bacteriological proof (CSF cultures) may explain the wrong diagnosis of bacterial meningitis in the first two episodes.

The CSF may be abnormal in up to 70 to $80 \%$ of $\mathrm{BD}$ cases with neurological involvement. The CSF protein concentration is moderately elevated in most of these patients, sometimes exceeding 1 $\mathrm{g} / \mathrm{dl}$, and oligoclonal bands are usually absent ${ }^{9}$. Elevated cellularity may be present, with polymorphonuclear predominance in the acute phase and lymphocytosis in the later stages, but the usual count is below 100 cells $/ \mathrm{mm}^{3}$. The presence of more than 1000 cells $/ \mathrm{mm}^{3}$, as in the case described here, is uncommon in $\mathrm{BD}$ cases?

The identification of focal neurological signs, associated with abnormalities in the imaging examinations and the good response to corticoid therapy in the third and fourth episodes, raised the possibility of a diagnostic hypothesis of inflammatory and demyelinating diseases of the Central Nervous System, such as acute disseminated encephalomyelitis, multiple sclerosis, neuromyelitis optica, sarcoidosis, and vasculitis. The fifth episode of recurrence, allied with better directing of the investigation of symptoms and the appearance of oral ulcers on this occasion, made it possible to reach the final diagnosis.

The characteristic MRI image in Neuro-Behçet 
are hyperintense T2/FLAIR lesions that are almost continuous in the most rostral portion of the brainstem and which extend to the thalamus and basal ganglia ${ }^{1}$. These findings are compatible with the case described here.

Our patient also presented two aneurysms. Cerebral aneurysms are present in only $0.2 \%$ of neurological conditions associated with $\mathrm{BD}$, a frequency that is slightly lower than that of the general population $(1.3 \%)$. The lack of signs of vasculitis in histopathological examinations on cerebral aneurysms in some patients with $\mathrm{BD}$ suggests more the possibility of coincidence than of a causal relationship ${ }^{1}$.

Studies on the management of Neuro-Behçet are scarce. However, there is practically a consensus that pulse therapy with intravenous corticoid therapy should be used. The use of immunosuppressants is indicated in cases in which there is a history of several previous episodes and the presence of aggressive disease such as diffuse meningoencephalitis ${ }^{1}$. In this manner, the prescription of methylprednisolone and azathioprine for our patient has backing in the current literature.

Since there is no specific test, the diagnosis of Neuro-Behçet depends on a high degree of suspicion. It is worth noting that the main differential diagnoses of the present case (meningitis and acute disseminated encephalomyelitis) do not require the same treatment as in BD cases (corticosteroid regimen and immunosuppression). Therefore, incorrect diagnosis implies a delay in introducing the correct therapy, thereby possibly leading to irreversible sequelae.

This case highlights the importance of placing Neuro-Behçet on differential diagnoses of recurrent meningitis. A high degree of suspicion and looking for signs and symptoms of this disease is the factor that will enable early therapeutic intervention, as soon as the disease has been recognized, thereby avoiding parenchymatous manifestations of greater severity.

\section{References}

1. Al-Araji A ,Kidd DP. Neuro-Behcet's disease: epidemiology, clinical characteristics, and management. Lancet Neurol 2009; 8: 192-204.

2. Criteria for diagnosis of Behçet's disease Lancet 1990; 335: 1078-80.

3. Akman-Demir G, Serdaroglu P, Tasci B. Clinical patterns of neurological involvement in Behcet's disease: evaluation of 200 patients. The Neuro-Behcet Study Group. Brain 1999; 122 (Pt 11): 2171-82.

4. Borhani Haghighi A. Treatment of neuro-Behcet's disease: an update. Expert Rev Neurother 2009; 9: 565-74.

5. Borhani Haghighi A, Safari A. Proposing an algorithm for treatment of different manifestations of neuroBehcet's disease. Clin Rheumatol 2010; 29: 683-6.

6. Gritti P, Lanterna LA, Chinaglia D, Manara O, Soavi L, Zilio A, et al. An unusual case of meningitis. Infez Med 2011; 19: 45-8.

7. Kidd D, Steuer A, Denman AM, Rudge P. Neurological complications in Behcet's syndrome. Brain 1999; 122 (Pt 11): 2183-94.

8. Suzuki N, Mizuno H, Nezu M, Takai Y, Misu T, Kuroda $\mathrm{H}$, et al. Procalcitonin might help in discrimination between meningeal neuro-Behcet disease and bacterial meningitis. Neurology 2009; 72: 762-3.

9. Siva A, Kantarci OH, Saip S, Altintas A, Hamuryudan V, Islak C, et al. Behcet's disease: diagnostic and prognostic aspects of neurological involvement. J Neurol 2001; 248: 95-103. 